\title{
Physicochemical and Microbial Assessment of Roadside Food and Water Samples in Lagos and Environs
}

\author{
${ }^{* 1}$ OPEOLU, B.O.; ${ }^{2}$ ADEBAYO, K.; ${ }^{3}$ OKUNEYE, P.A.; ${ }^{4}$ BADRU, F.A. \\ ${ }^{*}$ Department of Chemistry, Cape Peninsula University of Technology, Cape Town 8000, South Africa \\ ${ }^{2}$ Natural Resources Institute, University of Greenwich, Chatham Maritime, United Kingdom \\ ${ }^{3}$ Department of Agricultural Economics and Farm Management, University of Agriculture, Abeokuta, Nigeria \\ ${ }^{4}$ Department of Sociology, University of Lagos, Lagos Nigeria. \\ * Corresponding Author: Mobile:+27-730365373 E-mail: opeolubt@yahoo.com OR opeolub@cput.ac.za
}

\begin{abstract}
This study assessed the quality street vended food and water as well as the effects of environmental pollution on them in 3 local government areas (LGAs) representing low, medium and high income areas in Lagos State in coparison to samples collected from 5 locations in Ogun, Oyo and Osun States being previously established as places of origin of most migrants to Lagos. Street vended roasted plantain and maize as well as water samples were collected as composites from each of the sample locations. All samples were analysed for physico-chemical as well as microbiological parameters. The study revealed that roasted plantain in the low income area had the highest level of contaminants such as $\mathrm{Pb}, \mathrm{Cd}, \mathrm{Zn}$ and $\mathrm{Fe}$. The lowest value was in the high income area. Lead levels ranged between $0.2-125 \mu \mathrm{g} / \mathrm{g}$ with the highest value observed at the low income, high population density and high traffic area. $\mathrm{Cd}, \mathrm{Zc}$ and Fe levels also followed a similar trend in the other three States. They ranged between $0.48-18.3 \mu \mathrm{g} / \mathrm{g}, 2.0-4.5 \mu \mathrm{g} / \mathrm{g}$ and $0.4-13.5 \mu \mathrm{g} / \mathrm{g}$ respectively. It is opined that the pollution sources for the roasted plantain and maize include those from emissions from leaded gasoline. The aerobic mesophilic organisms, mould and Staphylococcus aureus were present in all the water samples. These results imply that government and its agencies should attend to the problem of unavailability of potable water and calls for greater monitoring and control of the environment where roadside foods are prepared. @ JASEM
\end{abstract}

Street vended foods can contribute significantly to food security of those involved in its production, particularly, suppliers of raw produce, food processors, vendors and consumers. Despite its growing importance, it is a sector that has rarely been the focus of strategic research initiative to determine its importance and potential hazards. The demand and supply of street foods is continually on the increase due to higher mobility status of people in the course of work. There is however, little or no regulation governing street food supplies (DFID, Undated). This has resulted in declining safety and quality of such foods. Problems associated with environmental contamination have also been exacerbated by consumption of such foods apart from littering of streets and cities with wastes generated from such consumption. Industrialization has also resulted in concentration of many chemicals in the atmosphere from where it enters into body fluids and different environmental media of soil, water, air, food, amongst others (Ajayi and Kamson, 1983; Ogunsola et al., 1994; Onianwa and Egunyomi, 1983). There has been and continues to be a good deal of public concern about the effects which the release of toxic chemicals may have on health. Heavy metals for instance, are known to have several adverse effects on man and animals. They include lead, zinc, mercury, arsenic, chromium, cadmium etc. each has particular effects on man and plants. For instance, mercury is known to cause nerve damage while arsenic causes lung cancer. Effects of lead on man include general metabolic poison which accumulates in body tissues such as red blood cells, liver and kidneys. It replaces calcium in bones which causes illness. Lead intake is responsible for metal fume fever as well as file cutters disease. Lead also causes depression and behavioural disorders in man. It can also cause abortion and neo-natal mortality. Toxic effects of different levels of lead exposure include acute encephalopathy which is characterised by lack of co-ordination, confusion, swelling of the brain and seizure and it may induce epilepsy, coma or even death (Forastieri, 1997). On man, chromium have irritant effects on skin and nasal tissues, it causes bronchitis, pneumonitis, gastro - intestinal, hepatic and renal impairments as well as embryo toxicity and other deleterious effects on reproduction (Baruthio, 1992). Zinc also causes metal fume fever in man. This is characterised by pulmonary manifestations, fever chills, gastro - enteritis has been observed to occur in industrial workers exposed to fumes. Accidental ingestion over two - day period causes, vomiting, fever and severe anaemia. Symptoms in humans include dehydration, electrolyte imbalance, abdominal pain, dizziness and muscular in co-ordination (Walsh et al., 1994). Mercury is absorbed in gastro intestinal tract, burns skin, lungs. It affects uterine mucosa. It also affects liver, brain, kidney and eyes (EHS, 2009). Copper causes nausea, vomiting, epigastric burning, diarrhea, systematic toxic effects include haemolysis, hepatic necrosis, gastro- intestinal bleeding, convulsions, coma or death. Street foods are also being exposed to disease causing micro- organisms resulting in epidemics of diseases such as cholera, dysentary, typhoid fever, amongst others. 
Since majority of workers eat at least, one street food per day as a regular meal, the importance of regular assessment of drinking water and street food quality and safety cannot be over-emphasized. Hence, the objectives of this study were to assess the quality as well as effects of environmental pollution on drinking water and street vended foods (roasted plantain and maize).

\section{METHODOLOGY}

Three (3) local government areas were selected for the study and 4 sample locations were chosen for each of the local government areas (LGAs). The LGAs represented low income, medium and high income areas. Roasted plantain and water samples were collected from the sample locations. These were analysed for the physico - chemical as well as microbiological parameters using standard methods (APHA, 1985; AOAC, 1984). Similarly, samples were collected from three States in South Western Nigeria, (Ogun, Oyo and Oshun) being previously established as places of origin of migrants to Lagos. 3 Local Government Areas were also selected in each of the states with 5 sample locations. Street vended roasted maize and water samples were collected as composites from each of the sample locations. The samples were then analysed for physico-chemical as well as microbiological parameters.

Table 1: Physico-Chemical Characteristics of Roasted Plantain at Lagos $(\mathrm{n}=15)$

\begin{tabular}{llll}
\hline $\begin{array}{l}\text { General Description } \\
\text { Odour and Taste }\end{array}$ & \multicolumn{1}{l}{ VI } & SU & KO \\
Characteristics of the Product & & \\
Moisture \% & $8.0 \pm 0.07$ & $8.2 \pm 0.01$ & $8.1 \pm 0.01$ \\
Total Ash \% & $2.2 \pm 0.03$ & $2.2 \pm 0.02$ & $2.3 \pm 0.01$ \\
Fat \% & $1.3 \pm 0.02$ & $1.2 \pm 0.15$ & $0.7 \pm 0.45$ \\
Crude Protein $(\% \mathrm{~N} \times 6.25)$ & $2.1 \pm 0.04$ & $2.0 \pm 0.01$ & $2.0 \pm 0.14$ \\
Lead $(\mu \mathrm{g} / \mathrm{g})$ & $0.2 \pm 0.01$ & $60.0 \pm 0.01$ & $125.0 \pm 3.28$ \\
Cadmium $(\mu \mathrm{g} / \mathrm{g})$ & $\mathrm{N} . \mathrm{D}$ & $0.48 \pm 0.01$ & $18.3 \pm 2.91$ \\
Zinc $(\mu \mathrm{g} / \mathrm{g})$ & $\mathrm{N} . \mathrm{D}$ & $2.0 \pm 0.03$ & $4.5 \pm 2.21$ \\
Iron $(\mu \mathrm{g} / \mathrm{g})$ & $0.4 \pm 0.01$ & $11.1 \pm 0.04$ & $13.5 \pm 0.45$ \\
\hline
\end{tabular}

Table 2: Microbial Characteristics of Roasted Plantain at Lagos $(n=15)$

\begin{tabular}{|c|c|c|c|}
\hline Microbial Group & VI & SU & $\mathrm{KO}$ \\
\hline Aerobic Mesophylic Organisms & $702 \pm 0.08$ & $718 \pm 0.05$ & $741 \pm 1.97$ \\
\hline Mould [CFU/g ] & $45 \pm 2.30$ & $55 \pm 1.81$ & $60 \pm 4.86$ \\
\hline Coliform [MPN/100g] & 0 & 0 & 0 \\
\hline E coli $[\mathrm{MPN} / 100 \mathrm{~g}]$ & 0 & 0 & 0 \\
\hline Staphyloccocus aureus CFU/g & $4 \pm 0.19$ & $4 \pm 0.14$ & $10 \pm 0.23$ \\
\hline
\end{tabular}

Table 3: Physico-Chemical Analysis of Domestic Water Samples from Lagos ( $n=15)$

\begin{tabular}{llll}
\hline Parameter & V1 & SU & Ko \\
Temperature $\left({ }^{\circ} \mathrm{C}\right)$ & $26.62 \pm 1.05$ & $26.7 \pm 0.80$ & $28.90 \pm 2.04$ \\
$\mathrm{pH}$ & $6.88 \pm 0.09$ & $6.70 \pm 0.08$ & $6.88 \pm 1.80$ \\
Conductivity $\left(\mu \mathrm{Scm}^{-1}\right)$ & $173.44 \pm 10.52$ & $180.75 \pm 17.91$ & $250.75 \pm 84.51$ \\
Alkalinity $(\mathrm{mg} / \mathrm{L})$ & $161.00 \pm 78.26$ & $38.75 \pm 5.67$ & $30.00 \pm 15.01$ \\
Chloride $(\mathrm{mg} / \mathrm{L})$ & $91.20 \pm 45.65$ & $19.5 \pm 0.98$ & $17.5 \pm 4.00$ \\
Dissolved Solids $(\mathrm{mg} / \mathrm{L})$ & $0.01 \pm 0.01$ & $0.09 \pm 0.01$ & $0.23 \pm 0.25$ \\
Total Hardness $(\mathrm{mg} / \mathrm{L})$ & $13.26 \pm 1.43$ & $13.25 \pm 2.84$ & $13.75 \pm 2.15$ \\
Lead $(\mathrm{mg} / \mathrm{L})$ & $0.23 \pm 0.01$ & $0.29 \pm 0.03$ & $0.61 \pm 0.09$ \\
Iron $(\mathrm{mg} / \mathrm{L})$ & $0.18 \pm 0.01$ & $0.23 \pm 0.46$ & $0.19 \pm 0.84$ \\
& & & 0.000 \\
\end{tabular}

Table 4: Microbiological Characteristics of Domestic Water Samples (LAGOS) n=15

\begin{tabular}{llll}
\hline Microbial Group & V1-1 & SU-1 & Ko \\
Aerobic Mesophilic Organisms (CFU/ml) & $22.80 \pm 3.68$ & $40.24 \pm 2.24$ & $46.40 \pm 6.98$ \\
Mould (CFU/ml) & 0 & 0 & 0 \\
Coliform (MPN/100ml) & 0 & $8.75 \pm 1.23$ & Zero \\
E. coli (MPN/100ml) & 0 & $6.00 \pm 0.80$ & Zero \\
\hline
\end{tabular}


Table 5: Some pollutants levels in street foods of Lagos and places of origin of migrants

\begin{tabular}{|c|c|c|c|c|c|}
\hline Pollutant & Lagos & Ogun & Oyo & Oshun & WHO Limit \\
\hline Lead $\mu \mathrm{g} / \mathrm{g}$ & $135.43 \pm 0.09$ & $0.055 \pm 0.21$ & $0.049 \pm 0.01$ & $0.061 \pm 0.04$ & N/A \\
\hline Iron $\mu \mathrm{g} / \mathrm{g}$ & $28.07 \pm 0.03$ & $12.65 \pm 0.19$ & $11.65 \pm 0.52$ & $14.51 \pm 0.47$ & N/A \\
\hline Total Counts cfu/ml & $10.00 \pm 0.23$ & $1.35 \times 104 \pm 0.11$ & $1.7 \times 103 \pm 0.89$ & $2.1 \times 104 \pm 0.45$ & Nil \\
\hline Bacteria Isolated & $\begin{array}{l}\text { Staphylococcus } \\
\text { aureaus }\end{array}$ & $\begin{array}{l}\text { Klebsiella sp, } \\
\text { Staphylococcus } \\
\text { aureaus }\end{array}$ & $\begin{array}{l}\text { S. aureaus, Proteus } \\
\text { spp }\end{array}$ & $\begin{array}{l}\text { Klebsiella sp, } \\
\text { Micrococcus sp }\end{array}$ & Nil \\
\hline Moulds Isolated & Aspergillus niger & $\begin{array}{l}\text { Rhizopus stolonifer, } \\
\text { Asperpergillus. niger, } \\
\text { Penincillium spp }\end{array}$ & $\begin{array}{l}\text { Aspergillus niger, } \\
\text { Yeast } \quad \text { Rhizopus } \\
\text { stolonifer }\end{array}$ & $\begin{array}{l}\text { Rhiz stolonifer, } \\
\text { Penincillium sp }\end{array}$ & Nil \\
\hline
\end{tabular}

Table 6: Some pollutants levels in domestic water samples of Lagos and places of origin of migrants

\begin{tabular}{llllll}
\hline Pollutant & Lagos & Ogun & Oyo & Oshun & WHO Limit \\
Lead $\mathrm{mg} / \mathrm{L}$ & $0.99 \pm 0.003$ & $0.40 \pm 0.130$ & $37.82 \pm 1.960$ & $19.82 \pm 0.991$ & 0.001 \\
Iron $\mathrm{mg} / \mathrm{L}$ & $0.58 \pm 0.020$ & $0.08 \pm 0.003$ & $0.01 \pm 0.002$ & $0.04 \pm 0.001$ & 0.3 \\
Nitrate $\mathrm{mg} / \mathrm{L}$ & $4.96 \pm 0.340$ & $2.32 \pm 0.540$ & $1.18 \pm 0.230$ & $0.82 \pm 0.005$ & \\
Coliform MPN/100ml & $9.90 \pm 0.180$ & $11.91 \pm 0.890$ & $69.82 \pm 2.67$ & $142.56 \pm 4.921$ & Zero \\
Mould cfu/ml & $0.01 \pm 0.001$ & $2.82 \pm 0.030$ & $4.96 \pm 0.74$ & $3.89 \pm 0.615$ & Zero \\
\hline
\end{tabular}
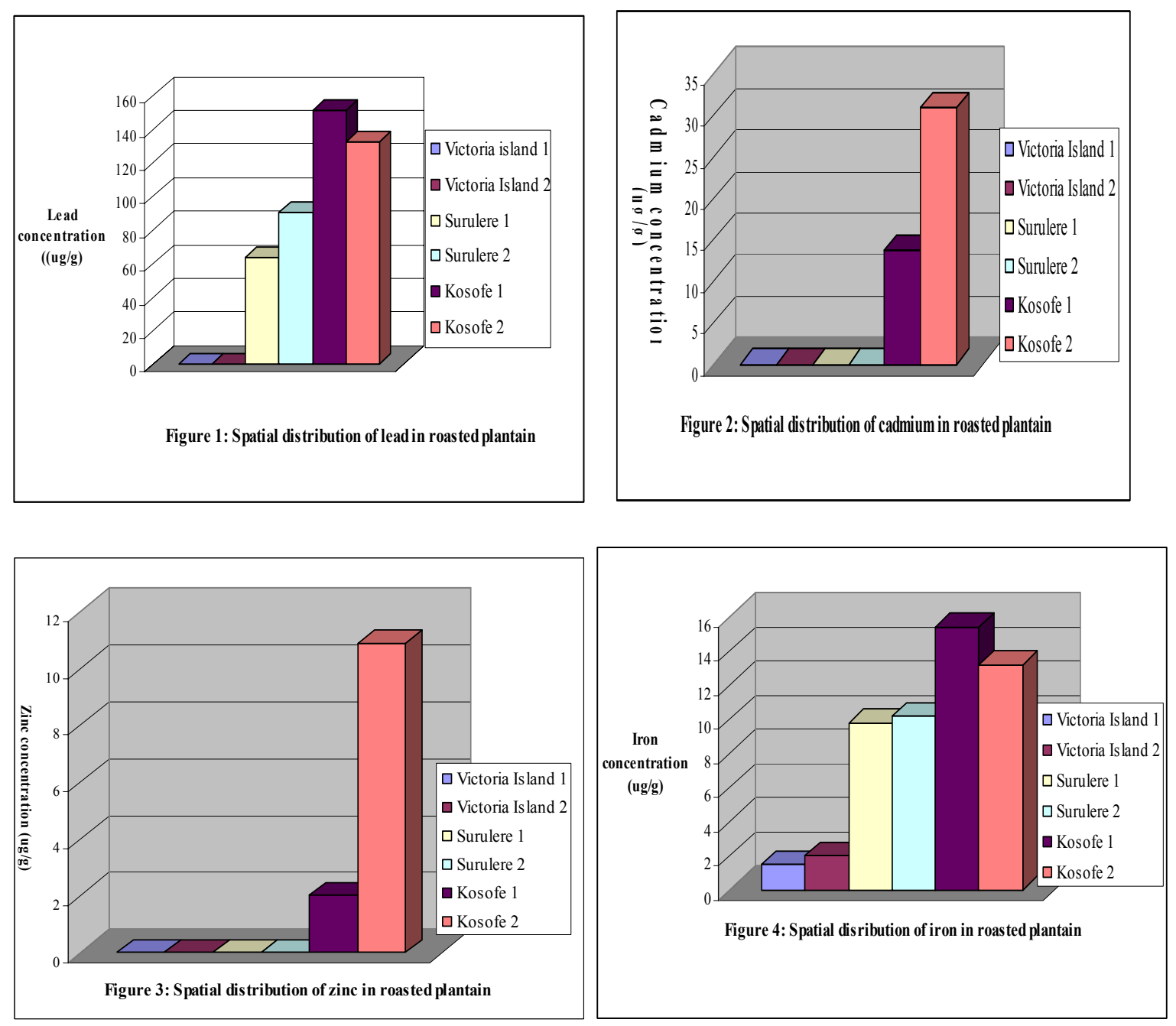

*Corresponding author: ${ }^{*}$ Opeolu, B.O. 


\section{RESULTS AND DISCUSSION}

The study revealed that roasted plantain in $\mathrm{KO}$, a low income area, had the highest level of contaminants such as $\mathrm{Pb}, \mathrm{Cd}, \mathrm{Zn}$ and $\mathrm{Fe}$. The lowest value was in $\mathrm{VI}$, the high income area. The result of the physicochemical characteristic of roasted plantain is shown on table 1 . The distributions of heavy metals' levels which are prominent chemical pollutants are presented in Figures 1, 2, 3 and 4. Samples from KO, (Kosofe LGA- a low income, high density and high traffic area) had the highest levels of various categories of contaminants while samples from VI (Eti-Osa LGA- a relatively high income, low density and low traffic area) had the least. Lead levels ranged between $0.2-125 \mu \mathrm{g} / \mathrm{g}$ with the highest value observed at the low income, high population density and high traffic area. Cadmium, zinc and iron levels also followed a similar trend, they ranged between $0.48-18.3 \mu \mathrm{g} / \mathrm{g}, 2.0-4.5 \mu \mathrm{g} / \mathrm{g}$ and $0.4-13.5 \mu \mathrm{g} / \mathrm{g}$ respectively. That is, the highest pollutant levels were observed at the low income, high density and high traffic density areas followed by the medium while the high income, low population density; low traffic density area had the least form of pollution. This work is consistent with the findings of Adekunle and Akinyemi (2004) who reported elevated levels of lead in street vended smoked fish in a Nigerian market. They established vehicular emissions as a major source of pollution of samples investigated. There appears to be a strong positive correlation (Correlation coefficient $=+0.998$ and +0.876 ) between pollutants concentration, traffic density as well as population of inhabitants.

In all the sample sites, the aerobic mesophilic organisms mould and staphylococcus aureus were present in all the samples (Table 2). The aerobic mesophilic organisms ranged between $680 \mathrm{CFU} / \mathrm{g}$ in $\mathrm{V} 1$ and $752 \mathrm{CFU} / \mathrm{g}$ in $\mathrm{KO}$. The trend of microbiological contamination is similar to those of chemical pollution in the sample locations. Mould ranged between $40 \mathrm{cfu} / \mathrm{g}$ in V1 and $62 \mathrm{CFU} / \mathrm{g}$ in $\mathrm{KO}$. Staphylococcus aureus occurrence was highest for KO while no growth was observed for VI and VI. Results of the microbiological analysis is in line with the work of Mosupye and Holy (2000) who reported the presence of pathogens in ready to eat foods such as sandwiches, ice creams sold in streets; some of the contaminants identified include E.coli, Staphylococcus aureus, Salmonella spp, amongst others.

The results of the physico-chemical analysis as well as the microbiological analysis of domestic water samples are shown on Tables 3 and 4 respectively.

The temperatures of the water samples were slightly higher than the recommended in all the sites. This can be attributed to the relatively high ambient air temperature in the tropics as against the normal $20^{\circ} \mathrm{C}$ in the temperate regions. The $\mathrm{pH}$ was also generally within the range recommended with the exception of one site each from $\mathrm{KO}$ and $\mathrm{SU}\left({ }^{*} \mathrm{Ko}-4\right.$ and $\mathrm{SU}-4$ respectively) that were slightly acidic. The acidification may probably be due to gaseous emissions fall out into major water bodies. This implies also that such water may have negative effects on man and his environment. The conductivity values lie within the limit recommended by WHO (1997) and this correlates with the low dissolved solids values of the water samples since there is a direct relationship between conductivity and dissolved solids. Alkalinity and chloride values in VI $(* V 1-4)$ was especially high. This may be due to soil formation around the area as well as the saline water from the ocean. Generally, all the water samples had lead pollution. Levels of lead were higher than the recommended. This may be attributed to metal pipes, raw water source, storage tanks amongst others. From the states of origin, results of physico-chemical analysis of roasted maize showed that the food quality of product was not significantly affected adversely in terms of nutrient content. However, there were variations in levels of chemical and microbiological contaminants in the products at the different sampling locations. Results are presented in table 5 and those for water samples are presented in table 6 . There were however no definite pattern of variation amongst the states. Within states, pollutants' levels seem to be higher in the urban areas than the rural areas in the three states. Values of Lead in roasted maize ranged between $0.02 \mu \mathrm{g} / \mathrm{g}$ and $0.061 \mu \mathrm{g} / \mathrm{g}$ in all the sample locations; range of iron in same was between 8.45 and $14.51 \mu \mathrm{g} / \mathrm{g}$. This may be attributed to higher vehicular traffic densities at Lagos than at the states of origin. This may be due to lead levels in Nigerian gasoline which has been reported to contain 0.4 to $0.8 \mathrm{~g} / \mathrm{L}$ (which is among the highest in the world) (Ogunsola et al., 1994) . Rankin et al. (2005) also reported that the emissions are reflected in the contamination of Nigerian dusts, plants and foods. Sources of pollutants likely to be processing method and atmospheric exposure since the pollutant have been documented to present in atmosphere (Ndiokwere, 1984).

Some of the microorganisms that were isolated and identified include Klebsiella sp Staphylococcus aureuas, Rhizopus stolonifer, Aspergillus niger, Penincillium spp, Proteus spp, Mucor mucedo, Yeast, Escherichia coli, Micrococcus spp. There were variations in results of microbiological examination of roasted maize from states of origin in contrast to those of Lagos (table 7). More species were identified and isolated at the states of origin than those of Lagos. This is an indication of less hygiene 
especially, environmental health. E. coli for instance is associated with feacal pollution and S.aureus is an indication of pollution arising from indiscriminate disposal of phlegm and sputum. By implication, personal and environmental hygiene is lacking or minimal at the states of origin. Comparative results of chemical and microbiological pollutants in water samples from Lagos and states of origin of migrants are presented in table 6 . Temperature ranged between $24^{\circ} \mathrm{C}$ and $29^{\circ} \mathrm{Che}$ sample locations. $\mathrm{pH}$ values in all locations fall within the WHO limit (6.5 - 8.5). Electrical conductivity values were above the WHO guidelines limit in almost all locations; this however indicates the presence of dissolved ions in the water samples. The trend was similar for chloride, alkalinity and hardness. Lead was present in all the water samples at toxic levels $(\geq 0.001 \mathrm{mg} / \mathrm{L})$ while the presence of iron was at trace levels in all samples. Bamgbose et al. (2001) reported that chemical changes or processes occurring along pipelines are factors that affect water quality. The samples (*except two, one from Ogun and Oyo) were feacally contaminated as expressed by the presence of coliform in the samples. Reasons for high values of chloride, alkalinity, may be alluded to the geological factors of the aquifers since most of the samples were from underground water sources. Coliform count suggests faecal contamination through seepage of septic tanks to water aquifers. Sangodoyin (1993) reported that unsanitary mode of disposal of wastes, such as defecation in streams and the dumping of refuse in pits, rivers and drainage channels as seen in most Nigerian urban settlements, could be expected to affect surface and groundwater quality. The degree of contamination will depend on the efficiency of waste disposal methods, safety on land use patterns, density of disposal systems in an area, composition of waste and a number of other site-specific information.

Pollution sources include those from emissions from leaded gasoline. Ajayi \& Kamson (1983) reported that the emissions are reflected in contamination of Nigerian dusts, plants and foods. It was however difficult to establish if the high levels were waste impacted or from storage vessels (Ndiokwere, 1984; Nriagu, 1992; Odukoya and Ajayi, 1987). Proximity to septic tanks leachates has also been reported to be responsible. Almost all pollution indices in water are higher in the samples from states of origin than Lagos. This may be attributed to improved quality of domestic/commercial water supplies resulting from governmental agencies campaigns on the need for hygiene and water sanitation in Nigerian cities. It also implies that government and its agencies should attend to the problem of unavailability of potable water in rural areas; this also applies to other basic infrastructures which in most cases attract people to urban areas.

\section{REFERENCES}

Adekunle, IM; MF (2004). Lead levels of certain consumer products in Nigeria: A case study of smoked fish foods from Abeokuta. Food Chem. Toxicol. 42(9):1463-1468.

Ajayi, A; Kamson, OE (1983). Determination of Lead in roadside dust in Lagos city by atomic absorption spectrophotometry. Environ Int. 9: $397-400$.

AOAC (1984). Official methods of analysis. $4^{\text {th }}$ Ed., Williams Association and official chemists Inc. Virginia, USA.

APHA (American Public Health Association) (1985). Standard methods for the examination of water and wastewater. $16^{\text {th }}$ Edition, Washington D.C..

Bamgbose, O; Arowolo, TA; Odukoya, O (2001). Comparison of drinking water quality in Abeokuta Township with WHO Standards. Water Resources- Journal of the Nigerian Association of Hydrogeologists (NAH). 12:3744.

Baruthio, F (1992). Toxic effects of chromium and its compounds. Biological trace elements Research.32(1-3):145-153.

DFID (Undated). Improving the safety of streetvended foods in Ghana (R 7493). Crop post harvest programme. Newsletter. 2pp.

Environmental Health and Safety (EHS) (2009). The health effects of mercury. Oklahoma State University.www.ehs.okstate.edu/training/mercury.htm

Forastieri, V (1997). Chemical Exposures: Children at Work - Health and Safety Risks; International Labour Organization. Geneva. Pp 114-115.

Mosupye, FM; Holy, A (2000).Microbiological hazard identification and exposure assessment of street food vending in Johannesburg, South Africa. Int. J. Food. Microbiol. 61:137-145.

Ndiokwere, CC (1984). A study of heavy metal pollution from motor vehicle emissions and its effect on roadside soil, vegetation and crops in Nigeria. Environmental Pollution Series Pp 3542. 
Nriagu, JO (1992). Toxic metal pollution in Africa. Sci. Total Environ 121: 1-37.

Odukoya, OO; Ajayi, SO (1987). Trace heavy metals in Nigerian Fish: lead and cadmium. Nig J. Nutri. Sci. 8: 105-113.

Ogunsola, OJ; Oluwole, AF; Osubiojo, IO; Durosinmi, MA; Fatusi, AO; Ruck, W (1994). Environmental Impact of Vehicular traffic in Nigeria. Health Aspects. Sci Total Environ. 146/147: 111-116.

Onianwa, PC; Egunyomi, A (1983). A Trace metal levels in some Nigerian mosses as indicators of atmospheric pollution. Environ. Pollut. Ser. B: 71-81.
Rankin, CW; Nriagu, JO; Aggarwal, JK; Arowolo, TA; Adebayo, K; Flegal, AR (2005). Lead Contamination in Cocoa and Cocoa Products: Isotopic Evidence of global Contamination. Environmental Perspectives. 113(10): 13441348 .

Sangodoyin, AY (1993). Considerations on contamination of groundwater by waste disposal systems in Nigeria. Environ. Technol. 14: 957964.

Walsh, CT; Sandstead, HH; Prasad, AS; Newberne, PM; Franker, PJ (1994). Environmental Health Issues. Environmental Health Perspectives Supplements 102(S2).

WHO (1997). Guidelines for drinking water quality. Surveillance and control of community supplies, Geneva. $\quad 2^{\text {nd }} \quad$ Ed. Volume 3. www.who.int/wwater sanitationhealth/dioq/guid elines/en. 